\title{
GENRE-BASED LANGUAGE LEARNING MODEL IN TEACHING WRITING SKILLS FOR ENGLISH DEPARTMENT STUDENTS
}

\author{
Haerazi \\ Email: haerazi@ikipmataram.ac.id \\ English Language Education, IKIP Mataram \\ Indonesia
}

\begin{abstract}
Writing is one of the language skills belongs to the productive skill. It is the most difficult skill because it is much more complex than the others. This is true since writing as thinking process where the learners must obtain ideas and manage ideas. Therefore, writing skill needs a special learning model for students. One of the approaches which are considered suitable to be implemented in teaching writing especially for teaching genre is genre-based language learning. Genre-based language learning is proposed to enable the learners to write a language linguistically accurate and socially appropriate. English teachers realize that writing is an important skill that foreign language learners need to develop. It is generally agreed that writing is the most difficult skill to master for foreign or second-language learners. There are four stages of teaching English using genre-based language learning; Building Knowledge of Field (BKOF), Modeling of Text (MOT), and Joint Construction of Text (JCOT), and Independent Construction of Text (ICOT).
\end{abstract}

\section{Key Words: Genre-Based Language Learning and Teaching Writing Skills}

\section{Introduction}

In foreign or second-language writing, a genrebased approach refers to teach learners how to make use of language patterns to achieve a coherent, purposeful composition (Hyland, 2003). Hyland adds that the genrebased approach has largely drawn on the theory of systematic functional grammar originally developed by Michael Halliday. This theory addresses the relationship between language and its social functions and sets out to show how language is a system from which users make choices to utter meanings.

Genre-based language teaching is considered to enable language learner to master all language skills. Teaching of language skills can be implemented in each stage of GBA. Teaching language skills, like speaking, listening, and reading, is able to be conducted by using GBA. GBA does not only focus on writing skill but also all language skills (Emilia, 2011: 31). Teaching of all language skills lies in each stage of GBA process that supports the developments of all language skills. According to Feez \& Joyce (2002: 28) and Emilia (2011: 33 ), there are five stages of teaching English using GBA, Those are building the context, modeling and deconstructing the text, joint construction of the text, independent construction of the text, and linking related text.

The genre has been used in many fields, including folklore studies, linguistic anthropology, ethnography of speaking, conversational analysis, rhetoric, literary theory, sociology of language and applied linguistics (Paltridge, 1997). However, the concept of genre to be discussed here will be based on one of the views of genre used in applied linguistics, in SFL theory in particular, in that genre is considered as text types. Simultaneously, any text is related to a genre, which may be more formally or more freely reproduced. Therefore, it is needed to think, methodologically, about the viability of the description of genres mainly if we consider that, we can only have access to those through empirical texts that are an example of genre.

In other words, the genre-based approach focuses heavily on the reader and on the conventions that a piece of writing needs to follow in order to be successfully accepted by its readership (Muncie, 2002). Using the genre-based approach, a teacher is required to get learners to write or produce a text or composition on the basis of purpose, organization and audience (Paltridge, 2001). Thus, a genre-based approach to the teaching of writing is one in which writing is viewed as both process and product of the whole processes of writing.

For these reasons, the writer proposes to apply genre-based language learning in teaching writing classes. In this case genre-based language learning is as alternative approach that can be used to help learners to develop their writing competence. Genre-based language learning is believed to bring some benefit when it can stimulate the learners to be eager to write. The implementation of genre-based language learning in teaching writing skills is assumed to be able to improve the learners' writing competence. 


\section{Genre-Based Language Learning}

Teaching language skills, like speaking, listening, and reading, is able to be conducted by using GBA. GBA does not only focus on writing skill but also all language skills (Emilia, 2011: 31). The concept of genre is primarily based on the idea that members of professional and academic communities usually have little difficulty in recognizing similarities in the texts they frequently use for specific purposes, and are able to draw on their repeated experiences with such texts to read, understand and write them relatively easily.

Teaching of all language skills lies in each stage of GBA process that supports the developments of all language skills. According to Feez \& Joyce (2002: 28) and Emilia (2011: 33), there are five stages of teaching English using GBA, Those are building knowledge of the field, modeling and deconstructing the text, joint construction of the text, independent construction of the text, and linking related text.

\section{Building Knowledge of Field (BKOF)}

This stage aims to build the knowledge of students about topics that will be written. The activities of this stage differ with the building knowledge of the text. Many teachers think that building knowledge of the field aims to explain the text that will be written by students such us explaining the generic structure and linguistic features of the texts, but it is inappropriate. If doing so, the teachers do not apply the building knowledge of the field but applying the building knowledge of the text (Emilia, 2011: 33).

To help students about topics that will be written, the teachers are able to teach all language skills such as reading, speaking, and listening. According to Emilia (2011: 33), the students are given any text relating the topics that will be written. This activity is able to be made as opportunity for teacher to teach reading, listening, or speaking activities. The teachers ask to students to discuss about the text based on their reading comprehension. The teachers also enable to teach grammar relating to some expression in texts. For instance, the teacher uses descriptive texts and its topics 'My Pet', the teachers give reading texts about it or listening video about it or speaking activities about Pet.

For these activities, the students are asked to read the first text and then they are given some questions about the text. From this activity, the teachers grade the students' reading comprehension. In this point, the teachers have done reading skill and they can apply against the reading techniques that they use usually, such as three phase techniques; pre-reading, whilst-reading and post-reading.

After that, the students identify some words and expressions that students do not understand from the text. The teachers also ask to the students to guess word or expression meaning from the text. If the students do not understand some vocabularies, the teachers allow to students opening the dictionary. From this stage, the students are taught by doing reading well, such as skimming, scanning, and predicting. Finally, the students are heard a topic that is teaching through tape recorder or the teachers read a text relating to the topic and the students hear it. The students also are given some questions about grammar and their comprehension of what they hear. Nevertheless, the teachers grade the students' listening skill in that time.

\section{Modeling of Text (MOT)}

This stage is designed to introduce and to familiarize the students with the discussion genre, so they could read it and deconstruct it. It is also aimed at building up students' understanding of the purpose, overall structure and language features of the genre. According to Amelia (2005: 153), the activities of Modeling involves in this stage are: (1) familiarizing students with the function and social context of the discussion genre; (2) presenting the schematic structure of the discussion genre; (3) presenting a model text of a discussion genre; and (4) presenting other texts in the discussion genre.

The first step is familiarizing the students with the power of the discussion genre in the social context of English (which takes a similar form in Indonesian) and the current Indonesian context. The step here stresses that the discussion genre, which weighs up two or more sides of an issue enables the students to practice the concept of decision making and conflict resolution through rational debate such as argument for, argument against, and recommended course of action (DSP in Amelia, 2005: 140). The second step is presenting and explicitly explaining the schematic structure of discussion genre on an overhead transparency. This aims to allow the teacher and students to share comment and to talk about the text as a class more easily. Each student is also given a copy which they could use for their own reference on future occasions when they write a discussion genre.

In presenting a model text of a discussion genre, the teacher creates the title of the text, for instance: should people receive more education than they need to function in their job? The teacher and students then collaboratively identified the purpose, the schematic structure, the function of each stage in the model text and the linguistic features. Then, the next stage is presenting other texts in the discussion genre. This stage, the teacher gives students the texts other than texts of genre given in advance. The other texts are used mainly to strengthen students' understanding of the schematic structure and to show the students various linguistic features and expressions that could be employed in their writing later. 


\section{Joint Construction of Text (JCOT)}

Emilia (2005: 144) mentioned that the steps of joint construction consist of five steps that are: (1) grouping the students into threes and familiarizing them with the task they would do in the stage; (2) approaching each group at the start of the Joint Construction; (3) consultation with each group on their draft.

First, grouping the students into threes and familiarizing them with the task they would do in the stage. This stage, the teacher first of all asks the students to make groups of threes, the members of which are entirely decided by them. The teacher then informs the students that activities conducts in this stage would be different form that they are used to, in that they would write a whole text (not only paragraphs as they are used to), in groups, in several sessions, during which consultations with the teacher is made. Moreover, the students are also reminded about the importance of note taking.

Second, approaching each group at the start of the Joint Construction; at this stage, the teacher approaches each group to see if they have any difficulty in starting their writing. To those who seemingly have difficulty, the teacher should propose some guiding questions, such as: what will you start with?; how many arguments or points will be included in the arguments for and against? Why will you take those arguments? Do you have enough data/evidence to support the arguments? In this case, the teacher stress that the arguments for and against should be balance (Emilia, 2005: 145).

Third, consultation with each group on their draft; in this consultation, the teacher focuses first of all on the strengths of the students' writing. This aims to encourage and reinforce students' first attempt at approximating the genre, even though the text produced may not contain all language features or show full control of the generic structure. At this stage, the teacher encourages the students to focus on all aspects of writing, modeled the process of writing, when the teacher would cross out, amend and add words (Amelia, 2005: 151).

\section{Independent Construction of Text (ICOT)}

The first case here may suggest students' consciousness of the impact of a text on different group of readers and their capacity to develop resistant reading or tactical reading (Martin in Emilia, 2005: 154). This also suggests students' emerging understanding that the writer's background does influence the way a text is constructed and that writing is relative to particular groups and contexts, and can be seen as one among many practices, which are open to scrutiny and contestation (Hyland, 2002: 48).

Moreover, the second case may seem from this stage above to evidence students' awareness of the impact of grammar, specifically mood of sentences or the use of modality and pronouns on power relations between the writers and readers and thus their awareness that nearly all aspect of language serve to express the power relations between participants in an interaction. Finally, the third occurrence seems to suggest the students' capacity to relate the text with their reality and to make sense of the world around them.

After the discussions, when students have sufficient background knowledge about the topic and are ready to write independently based on students' agreement, the teacher moves on to the independent construction. Feez \& Joyce (2002: 31) describe that the independent construction of the text is that the students work independently with the text and student performances are used for achievement assessment.

\section{Teaching Writing}

When writing skill has been explicitly taught in higher education, the emphasis has been on students' writing as final texts or products. Teaching writing skills, whether in formal writing classes or as an activity, often needs to present language learners with 'models of good writing', and asking them to imitate those exemplars. Often, little analysis occurred of the various rhetorical aspects of the texts or the social contexts in which the texts functioned. Coffin Cs (2003: 10) states that "the focus instead is on specific features of the written texts, for example, spelling, text structure, vocabulary, style.

Coffin Cs (2003: 11) states that "attention in process approaches to writing is paid to the steps and stages of writing that an individual writer might work through." Process writing emerged from the individualist, expressivist impulse popular throughout education. Following the notion of the discrete, isolated individual, the emphasis in process writing is chiefly on how students could express their identities, rather than on writing as something that occurs in a social context. Critics of process approaches have been argued by some linguists that explicit teaching of the forms and conventions of academic writing must accompany any focus on process in order for students to gain control of dominant academic forms.

Here the focus is on writing as an activity that often occurs in a social context of language community, at both a more local, immediate level and at a broader social and cultural level. In the context of higher education, there are different ways in which student writing can be understood as a 'social practice'. Thus academic writing is also about personal and social identity. Some students may find it harder or less comfortable to take on these identities than others. This focus on identity in academic writing has been emphasized in recent times; educational background, ethnicity, cultural expectations and gender have all been shown to influence how students read academic texts and respond in writing (Ivanic, 1998; Lillis, 2001). 


\section{References}

Anderson, N. (2003). Reading. In D. Nunan (Ed.), Practical English language teaching (pp. 67-86). New York: McGraw-Hill.

Bruce, I. (2008). Academic writing and genre: A systemic analysis. British: Continuum.

Bakhtin, M. (1986). Speech genres and other late essays. Austin: university of Texas Press.

Emilia, E (2011). Pendekatan genre-based dalam pengajaran bahasa Inggris: Petunjuka untuk Guru. Bandung: Rizki Press.

Emilia, E. (2005). A critical genre based approach to teaching academic writing in a tertiary EFL context in Indonesia, $\mathrm{PhD}$ thesis, Dept of Language, Literarcy and Arts Education, University of Melbourne.

Feez, S. (1998). Text-based syllabus design. Sydney: NCELTR-Macquarie University.

Hyland, K. (2002). Genre: language, context, and literacy. Annual review of applied linguistics, 22, 113-135

Hyland, K. (2003). Second language writing. New York: Cambridge University Press.

Hyland, K. (2003). Genre-based pedagogies: A social response to process. Journal of Second Language Writing, Vol. 12 pp. 17-29.

Hyon, S. (2002). Genre and ESL reading: A classroom study. In John, A.M. editor, Genre in the classroom. Mahwah: Lawrence Earlbaum Associates Publishers.

John, A.M. (2002). Genre in the classroom. Mahwah: Lawrence Earlbaum Associates Publishers.
Knapp, P. \& Watkins, M. (2005). Genre, text, grammar: technologies for teaching and assessing writing. Wales: UNSW Press Book.

Liddicoat, A,J. et al. (2003). Report on Intercultural language learning. Austrlian Government, Department of Education, Science and Training. The university of South Australia. Australia: Commenwealth of Australia.

Liddicoat, A.J. (2011). Language teaching and learning from an intercultural perspective. In Hinkel. Handbook of Research in second language teaching and learning. Second edition. Francis: Routledge.

Liddicoat, A.J. and Scarina, A. (2013). Intercultural language teaching and learning. Melden: Wiley Blackwell.

Muncie, J. (2002). Finding a place for grammar in EFL composition classes. ELT Journal, 56, 180-186.

Paltridge, B. (2001). Genre and the language learning classroom. Ann Arbor, MI: University of Michigan Press.

Rezvani, P., Aqdam, S.K, \& Saeidi, M (2008). The Effect of Genre-Based Teaching upon EFL Writing Achievement. Journal of Islamic Azad University, Iran.

Widodo, H. J. (2006). Designing a genre-based lesson plan for an academic writing course. International Journal of English Teaching: Practice and Critique, Vol.5 No.3. Pages. 173199. 